\title{
Agrobacterium - caused transformation of cultivars Amaranthus caudatus L. and hybrids of A. caudatus L. $x$ A. paniculatus $\mathrm{L}$.
}

\section{Olha Mikolaivna Yaroshko (iD,,1, Mykola Vyktorovych Kuchuk ${ }^{1}$}

${ }^{1}$ Institute of Cell Biology and Genetic Engineering NAS of Ukraine, Kyiv, Ukraine

Abstract: The procedure for vacuum infiltration of cultivars A. caudatus L. and hybrids of $A$. caudatus L. x A. paniculatus L. was optimized. The functioning of gene construction pCBv19 in the Amaranthus leaves was evaluated by the transient expression after vacuum infiltration with Agrobacterium rhizogenes A4. After hypocotyl transformation of the varieties of amaranth species A. caudatus L.: Helios, Karmin, Kremovyi rannii, and hybrids $A$. caudatus x A. paniculatus L. - cv. Sterkh, A. caudatus x Sterkh- cv. Zhaivir with the wild strain A. rhizogenes A4, the culture of "hairy roots" was obtained. Embedding and transcription of genes in the roots are confirmed by the results of the PCR analysis.

\section{ARTICLE HISTORY}

Received: 18 June 2018

Revised: 19 October 2018

Accepted: 01 November 2018

\section{KEYWORDS}

Amaranthus,

Agrobacterium,

transformation, transgenic roots.

\section{INTRODUCTION}

Amaranth plants are used in the food industry, medicine, cosmetics and agriculture, they are also a source of biologically active compounds, the most valuable of them are squalene and amarantin. Squalene has anticancer and wound healing properties while amarantin - has an antioxidant activity $[1,2]$. The seeds of Amaranthus species are rich in methionin and lysine amino acids. Biologically valuable substances can be obtained by using biotechnological methods.

Plants that synthesize alien substances may well be received through genetic transformation by using Agrobacterium bacteria. Members of this genus are pathogens. Due to $\mathrm{Ti}-$ and $\mathrm{Ri}$ - plasmids these bacteria can cause the formation of plants «hairy roots» $(A$. rhizogenes) or tumors (A. tumefaciens). The hormonal balance of plants changes (after insertion and expression of bacterial gene), which results in specific phenotype in infected plants [3].

CONTACT: Olha Mikolaivna Yaroshko \90tigeryaroshko90@gmail.com Institute of Cell Biology and Genetic Engineering NAS of Ukraine, Kyiv, Ukraine 
Initial experiments connected with the transformation of amaranths species with Agrobacterium strains were unsuccessful [4]. By then, it was proved that transgenic amaranths plants with A. rhizogenes and A. tumefaciens could be obtained. But still there are only several works devoted to the transformation of amaranth.

The transgenic roots were obtained for Amaranthus tricolor [5] and A. spinosus L. [6]. The transgenic plants were obtained for A. hypochondriacus L. and A. tricolor L. [7, 8], A. retroflexus, A. viridis, A. cruentus [9]. There is no information about transformation of $A$. caudatus, the varieties of which is also used in agriculture.

The aim of this work was to evaluate the functioning of gene construction pCBv19 of Agrobacterium rhizogenes A4 in amaranth tissues and obtain transgenic roots of amaranth after genetic transformation with using the wild strain of A. rhizogenes A4.

\section{MATERIALS and METHODS}

\subsection{The transient expression of transferred genes in the leaves of Amaranthus}

The objects of the research were cultivars of species of Amaranthus caudatus L.: Helios, Karmin, Kremovyi rannii, hybrids: A. caudatus x A. paniculatus L. - cv. Sterkh, A. caudatus x Sterkh - cv. Zhaivir.

Our objective was to check and evaluate the functioning of gene construction pCBv19 of A. rhizogenes A4 (Fig. 1) in transiently transformed amaranth leaves.

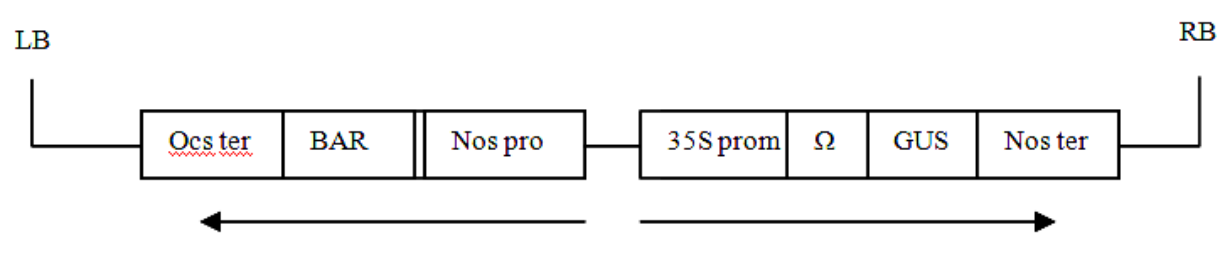

Fig. 1. Schematic representation of the T-DNA site of the pCBv19 construction LB - left border sequence, RB - right border sequence; Nos pro - nopaline synthase promoter, Nos ter - nopaline synthase terminator; 35S prom - 35S promoter; BAR - bar gene, GUS - gus gene; Ocs - octopine synthase; $\Omega$ - regulatory sequence enhancer

For this purpose we used the method of vacuum infiltration [10] and detection of GUS activity [11]. For infiltration of the 2-month-old plant leaves, the varieties and hybrids mentioned above, were used. As an infection agent we used A. rhizogenes A4 gene construction $\mathrm{pCBv} 19$, which contained bar and gus genes.

First, A. rhizogenes A4 was sown in the liquid LB medium (for $24 \mathrm{~h}$. mixing on shaker). We added $1 \mathrm{ml}$ of $A$. rhizogenes into $50 \mathrm{ml}$ of the medium with $0,2 \mathrm{mM}$ of acetosiringone. Next, Agrobacterium was centrifuged during $12 \mathrm{~min}, 5000 \mathrm{rpm}$. Then, Agrobacterium was resuspended into the medium with sucrose $(50 \mathrm{~g} / 1+0,2 \%$ super wetting agent Silwet).

The next stage was dipping the leaves of amaranth into the flask with the medium containing A. rhizogenes (for 5-10 $\mathrm{min}, 22-24 \mathrm{C}^{0}$ ) in the vacuum chamber. After this operation, leaves were put on the wet filter paper in Petri plates (Fig. 4).

After the leaves had been lying on the wet filter paper for 4 days, $\beta$ - glucuronidase fluorometric assay (GUS activity) was conducted at $37{ }^{\circ} \mathrm{C}$ according to Jefferson [11]. GUS reactions were stopped in $24 \mathrm{~h}$. of incubation at $37^{\circ} \mathrm{C}$. Specific activities were detected visually by the appearance of staining the plant tissues in blue color. 


\subsection{Transgenic roots obtaining}

Seeds of amaranth germinated on the sterile nutrient agar medium Murasige and Skoog $\left(\mathrm{MS}_{30}\right)$ [12] with $30 \mathrm{~g} / \mathrm{l}$ sucrose. For transformation we used the hypokotyl segments of 14day-old seedlings of cultivars of the following species A. caudatus L.: Helios, Karmin, Kremovyi rannii, and hybrids: A. caudatus x A. paniculatus L. - cultivar Sterkh, A. caudatus $\mathrm{x}$ Sterkh - cultivar Zhaivir, the seeds were obtained from the Botanical Garden of M.M. Grishko NAS of Ukraine. Transformation was carried out by co-cultivating the hypokotyls with the agropine strain of $A$. rhizogenes A4. Transformation of amaranths was carried out according to the modification of techniques proposed by Jofre-Garfias and colleagues [13].

First, A. rhizogenes A4 was sown in the liquid LB medium (for $24 \mathrm{~h}$. mixing on shaker). We used $1 \mathrm{ml}$ of A. rhizogenes into $50 \mathrm{ml}$ of the medium with $0,2 \mathrm{mM}$ of acetosiringone. Next, Agrobacterium was centrifuged during $12 \mathrm{~min}, 5000 \mathrm{rpm}$. Then, Agrobacterium was resuspended into the medium liquid $1 / 2 \mathrm{MS}_{15}$. In this medium explants were soaked for 2 hours.

After 2 hours of incubation, explants were transferred on the solid growth medium $1 / 2 \mathrm{MS}_{15}$ without antibiotics. Co-cultivation on this medium lasted 1 day and then the hypocotyls transferred on the $1 / 2 \mathrm{MS}_{15}$ medium with the addition of $500 \mathrm{mg} / \mathrm{l}$ of cefotaxime ("Darnitsa", Ukraine).

Every 2 weeks hypocotyls were transferred to the $1 / 2 \mathrm{MS}_{15}$ medium with a reduced content of cefotaxime $(400 \mathrm{mg} / \mathrm{l}, 300 \mathrm{mg} / \mathrm{l}, 200 \mathrm{mg} / \mathrm{l})$. In the last transfer we used $1 / 2 \mathrm{MS}_{15}$ medium without adding of cefotaxime.

Hypocotyls of 14-day-old seedlings of the same varieties were used as a control, which weren't cocultured with $A$. rhizogenes A4, first, they were laid out on $1 / 2 \mathrm{MS}_{15}$ medium, then on $1 / 2 \mathrm{MS}_{15}$ with $500 \mathrm{mg} / \mathrm{l}$ of cefotaxime. The following sub-cultivation for control samples were not carried out, because after 15 days the hypocotyls died.

\subsection{Polymerase chain reaction}

Genomic DNA isolated by CTAB method [14]. For the PCR analysis we used the reaction mixture of the following composition: $2 \mu$ single PCR buffer with ammonium sulphate (Dream Taq Green Buf.), $2 \mu 1$ primers, $2 \mu 1$ deoxyribonucleotide triphosphate (dNTP), $0.15 \mu 1$ Dream Taq-polymerase, $2 \mu 1$ DNA (20-30 ng/ml DNA). The volume of the reaction mixture is $20 \mu 1)$.

To identify the gene $\mathrm{rolB}$, the primers were used: 5 '-CTCACTCCAGCATGGAGCCA3' as well as 5'-ATTGTGTGGTGCCGCAAGCTA-3'. The expected size of the amplification product for $\mathrm{rolB}$ gene was $592 \mathrm{bp}$. Amplification conditions: initial denaturation at $94{ }^{0} \mathrm{C}$ for 3 min, annealing at $60{ }^{\circ} \mathrm{C}$ for $30 \mathrm{~s}$, extension at $72{ }^{\circ} \mathrm{C}$ for $30 \mathrm{~s}$ for the first cycle followed by 32 cycles each. The duration of the synthesis of the $\mathrm{rolB}$ was $40 \mathrm{~s}$, at $72{ }^{\circ} \mathrm{C}$, final polymerization was at $72{ }^{\circ} \mathrm{C}$ for $5 \mathrm{~min}$.

\section{RESULTS}

For evaluation of functioning of Agrobacterium rhizogenes A4 gene construction pCBv19 in Amaranthus tissues, we carried out the histochemical reaction [11] (Fig.2, Fig. 3). 


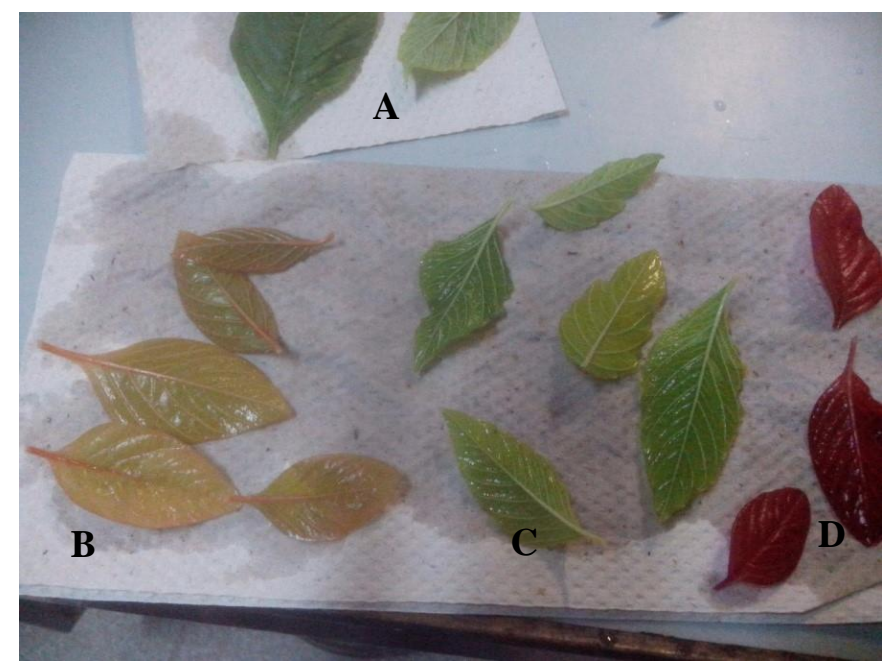

Fig. 2. Leaves of varieties A - Kremovii ranii, B - Helios, C - Rushnichok, D - Karmin after infiltration under vacuum.
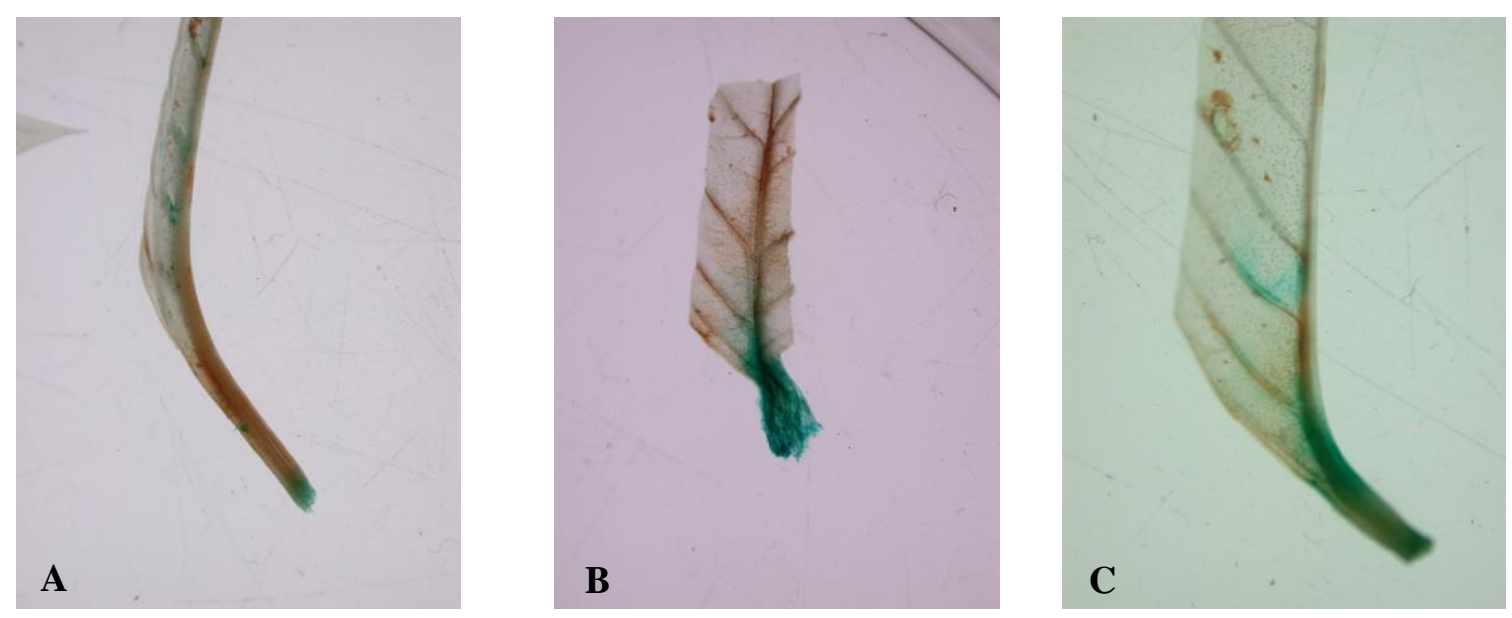

Fig. 3. Leaves of varieties A - Kremovii ranii, B - Helios, C - Rushnichok, D - Karmin after a histochemical reaction (detection the activity of GUS).

The GUS activity result was positive for 2 varieties (Karmin and Helios) (sites that are of blue color). Positive sites were in the area of the midrib (Fig.3). At the next stage transgenic roots were obtained. The growth of "hairy roots" of Amaranthus on the hypocotyl explants were observed in 20-25 days after A. rhizogenes transformation on the $1 / 2 \mathrm{MS}_{15}$ medium with cefotaxime. Eight lines of roots were received. When transferred the parts of the roots $(\sim 10 \mathrm{~mm})$ on the hormone free medium without growth regulators, their intensive growth was observed. The roots outwardly resembled "hairy roots" (Ri- roots) form (Fig. 4), due to transfer of TL- fragment of the T-DNA of pRi plasmid of the agropine type with gene rolB. 


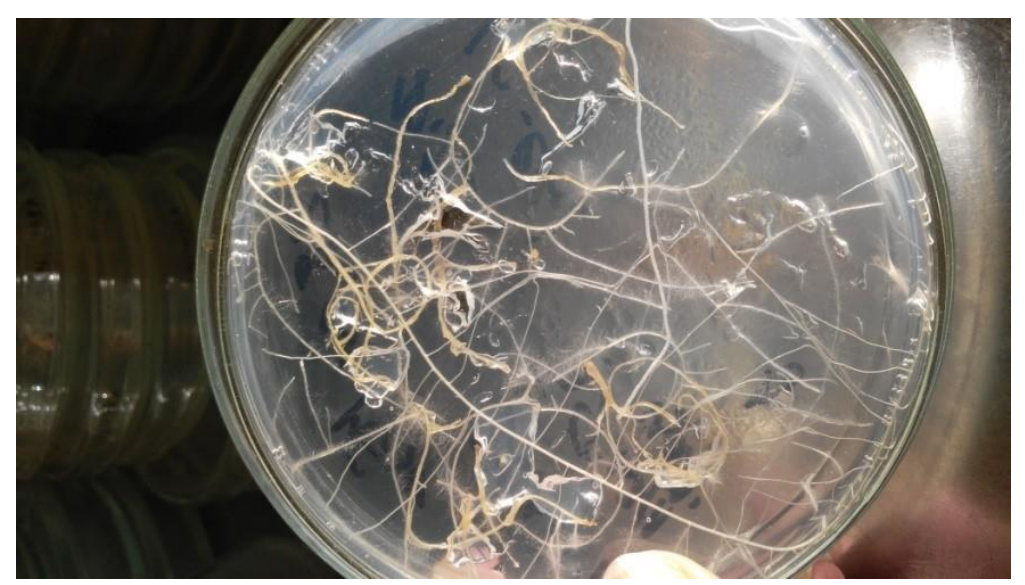

Fig. 4. Formation of "hairy roots", after transformating the hypocotyls of A. caudatus Helios with the strain A. rhizogenes A4

To confirm the presence in the transformed roots TL-fragment of the T-DNA pRi plasmid, the amplification of total DNA with primers, specific to rolB gene, was carried out. During the analysis of 8 samples of tested cultivars of species A. caudatus L.: Helios, Karmin, Kremovyi rannii, and hybrids: A. caudatus x A. paniculatus L.- cv. Sterkh, A. caudatus x Sterkh - cv. Zhaivir, the presence of the DNA fragment with 592 bp size for 3 samples (№3 Helios; №6, №8 - Karmin), was discovered, this confirms the presence of the rolB gene in the transformed roots (Fig. 5).

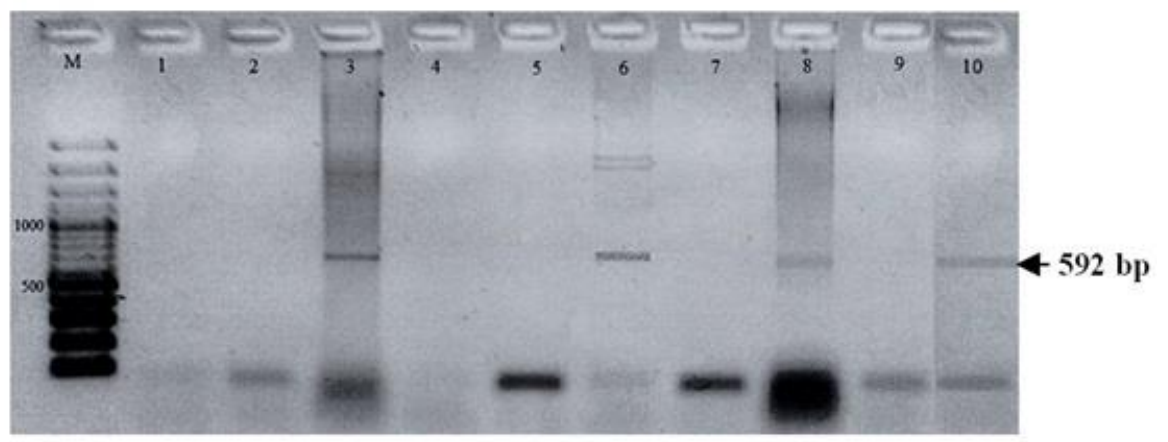

Fig. 5. PCR analysis of amaranth plants using primers for rolB gene: $M$ - DNA marker (O'GeneRuler ${ }^{\mathrm{TM}} 1 \mathrm{~kb}$ DNA Ladder, "Fermentas"), 1-8 total DNA of plants transformed with $A$. rhizogenes A4 (1 - Sterkh; 2, 3, 4 - Helios; 5- Kremovyi rannii; 6, 8 - Karmin; 7 - Zhaivir), 9 - negative control, DNA non-transformed plants, 10 - positive control, the plasmid DNA of A. rhizogenes A4 (592 bp).

\section{DISCUSSION}

Positive results were obtained in the transformation of Amaranth tricolor L. - Swain with colleges [5] and Amaranth spinosus L. - Pal and colleges [6] with the wild strains of Agrobacterium rhizogenesis A 4. The authors get transgenic roots. Positive results were obtained in the transformation of amaranth species with strains of Agrobacterium tumefaciens. Jofre-Garfias with co-authors - Amaranthus hypochondriacus L., cv. "Azteca". They used Agrobacterium construction with marker genes [13]. Transgenic Amaranthus tricolor L. was obtained by two different groups of scientists - Swain with colleges and Pal with co-authors [7, 8]. Pal with co-authors used the construction with marker genes. Also there are 2 works dedicated to the transformation through amaranth inflorescence - Umaiyal Munusamy with co-authors. They used the construction with selective genes [15]. 
Prof. Taipova conducted experiments with Amaranthus retroflexus, A. viridis, A. cruentus [9]. In both works it is said that positive and promising results were obtained and they get transgenic seeds. The results obtained don't seem convincing. Since in the work by Umaiyal Munusamy it isn't indicated with what kind of amaranth they worked. Prof. Taipova didn't indicate with what kind of bacteria they worked. The results of the biochemical and genetic analysis aren't shown, referring to which it would be possible to state with accuracy that they received transgenic seeds.

We have for the first time obtained transgenic plant parts for the varieties of Amaranthus caudatus L. Since, there are still no reports on the transformation of A. caudatus. The PCR analysis shows that not all the "hairy root" samples carried the genes of the Agrobacterium, although all the variants were phenotypically identical and were similar to typical "hairy roots", grew on the hormone-free $\mathrm{MS}_{30}$ medium. The results of the GUS activity were also not positive for all explants. Only $25 \%$ of the leaf samples showed a positive result. Positive results for the GUS activity were obtained for the Karmin and Helios varieties. Transgenic roots were obtained for the same varieties. The reasons for that are still not clear. Perhaps these varieties are more susceptible to Agrobacterium rhizogenesis than the other varieties which we tested. To clarify these reasons, further researches will be required.

\section{CONCLUSION}

So, after the vacuum infiltration of leaves, the GUS activity result was positive for 2 varieties of A. caudatus: Karmin and Helios. After the transformation of hypocotyls of cultivars of amaranth species of Amaranthus caudatus L.: Helios, Karmin, Kremovyi rannii, and hybrids: A. caudatus x A. paniculatus L.- cultivar Sterkh, A. caudatus x Sterkh - cultivar Zhaivir, using A. rhizogenes A4, were obtained transgenic roots of cultivars Helios and Karmin. The analyzed samples had gene rolB of $A$. rhizogenes.

\section{ORCID}

\section{Olha Mikolaivna Yaroshko (D) https://orcid.org/0000-0003-2517-4472}

\section{REFERENCES}

[1]. Biswas, M., Das, S. S., Dey, S. (2013). Establishment of a stable Amaranthus tricolor callus line for production of food colorant. Food Sci. Biotechnol, 22, 22 - 30.

[2]. Yaacob, J. S., Hwei, L.C., Taha, R.M. (2012). Pigment analysis and tissue culture of Amaranthus cruentus L., Acta horticulturae, 54 - 64.

[3]. Draper, J., Scott, R. (1991). The isolation of plant nucleic acids. In Plant Genetic Engineering Edited by Don Garierson. Blackie, London, pp. 240-244.

[4]. De Cleene, M., De Ley, J. (1976). The host range of Crown Gall. Bot. Rev. 42, 389-466.

[5]. Swain, S. S., Sahu, L., Barik, D. P., Chand, P. K. (2010). Agrobacterium $\times$ plant factors influencing transformation of "Joseph's coat" (Amaranthus tricolor L.). Scientia Horticulturae, 125, 461-468.

[6]. Pal, A., Swain, S. S., Mukherjee, A. K. \& Chand, P. K. (2013). Agrobacterium pRi TLDNA rolB and TR-DNA Opine Genes Transferred to the Spiny Amaranth (Amaranthus spinosus L.) - A Nutraceutical Crop. Food technology and Biotechnology, 51 (1), 26-35.

[7]. Swain S. S., Sahu L., Barik D. P., Chand P. K. (2009). Genetic transformation of Amaranthus tricolor L. using Ri plasmid vectors. In: Bastia, A.K. and Mohapatra, U.B. (eds.) Recent trends in monitoring and bioremediation of mine and industrial environment. Proc. Natl. Sem., North Orissa University, Orissa, 109-116.

[8] Pal, A., Swain, S. S., Das, A. B., Mukherjee, A. K., Chand, P. K. (2013). Stable germ line transformation of a leafy vegetable crop amaranth (Amaranthus tricolor L.) mediated by 
Agrobacterium tumefaciens, In Vitro Cell. Dev. Biol.-Plant, 114 -

128. https://link.springer.com/article/10.1007/s11627-013-9489-9 doi: 10.1007/s11627013-9489-9

[9]. Taipova R. M., Kuluev B. R. (2015) Amaranth features of culture, prospects of cultivation in Russia and generation of transgenic Russian varieties, Biomica, v. 7, 4, 284 299.

[10]. Martins, P.K., Nakayama, T.J., Ribeiro, A.P., Cunha Badbd, Nepomuceno, A.L., Harmo n, F.G., Kobayashi, A.K., Molinari, H.B. (2015) Setaria viridis floral-dip: A simple and rapid Agrobacterium-mediated transformation method, Biotechnol. Rep. (Amst.). https://www.ncbi.nlm.nih.gov/pubmed/28435809 doi:10.1016/j.btre.2015.02.00 6

[11]. Jefferson, R. A. (1987). Assaying chimeric genes in plants: the gus gene fusion system, Plant. Mol. Biol. Rep., 5, 387-405.

[12]. Murashige, T., Skoog, F. (1962). A revised medium for rapid growth and bioassays with tobacco tissue cultures, Physiologia Plantarum, 15, 473-497.

[13]. Jofre-Garfias, A.E., Villegas-Sepúlveda, Cabrera-Ponce J.L., Adam e-Alvarez R.M., Herrera-Estrella, L., Simpson J. (1997). Agrobacterium mediated transformation of Amaranthus hypochondriacus: light- and tissue-specific expression of a pea chlorophyll a/b-binding protein promoter, Plant Cell Reports, 16, 847-852.

[14]. Stewart, C. N., Via, L. E. (1993) A Rapid CTAB DNA isolation technique useful for Rapid fingerprinting and other PCR applications, BioTechniques, v. 14 (5), 748-749.

[15]. Umaiyal Munusamy, Siti Nor Akmar Abdullah, Maheran Abd Aziz, Huzwah Khazaai (2013). Female reproductive system of Amaranthus as the target for Agrobacteriummediated transformation, Advances in Bioscience and Biotechnology, 4, 188-192. http://dx.doi.org/10.4236/abb.2013.42027 